\title{
Marketing in Facebook
}

\author{
Sriteja $\mathbf{V}^{1^{*}}$, Vinay $\mathbf{V}^{2}$, Hemalal $\mathbf{R}^{3}$, Sushma $\mathrm{B}^{4}$, Venkatesh TV \\ ${ }^{1}$ University of Wolverhampton, United Kingdom \\ ${ }^{2} P G$ Diploma in Human Resources, Andhra Pradesh Productivity Council, Hyderabad, India \\ ${ }^{3}$ University of Hyderabad, India \\ ${ }^{4}$ SRM University, Chennai, India \\ ${ }^{5}$ Master's in Business Administration, Andhra University, India
}

*Corresponding author: Sriteja V, University of Wolverhampton, United Kingdom, Tel: +917799083993; E-mail: sriteja_volam@yahoo.com

Rec date: Jun 19, 2014, Acc date: Jun 20, 2014, Pub date: Jun 25, 2014

Copyright: (c) 2014 Sriteja V, et al. this is an open-access article distributed under the terms of the Creative Commons Attribution License, which permits unrestricted use, distribution, and reproduction in any medium, provided the original author and source are credited.

\begin{abstract}
This paper explains how social media is increasing its importance in achieving it as a marketing channel for collecting information of the products and the services given by the company. Many brands are marketing their brand awareness in social media; this paper tells how the social media is used for marketing their brand in a smart way. With the growing popularity of social media such as Facebook and orkut the growth of users are increasing day by day by which the company can make aware of their product in a simple way by sharing it on the walls of the company's home page.
\end{abstract}

Keywords : Facebook; Social media; Social network; Marketing and Internet.

\section{Introduction}

Facebook is a social networking site which gives its services by online, Facebook was founded on February 4, 2004 by a young Graduate named Mark Zukerberg And his Friends from Harvard University. User must first get registered in Facebook site then after he can create his own profile and from the main thing starts, adding friends, sharing the interesting topics, sharing their interest on the walls of their profile, there are few interesting things like sharing the post liking it or commenting on the post by which they can know is person is exited with that post or disappoint with the post they can find out the response of their friends directly on the wall of their profile [1]. Here we go where the marketing people are really using this platform very well to project their company or the products of the company. Few tips for marketing your Brand on Facebook,

Fix a target: what result you are willing to get, Make your page interesting for viewers, present the product details in clear cut manner. Present an impressive description about your product, update your page frequently, try to know the comments of viewers so that we can modify the page according to their idea, Facebook is a platform where marketers cannot ignore the valuable platform [2]. In the past 20 years the usage of internet as marketing tool, whether the organization is small or big it is been used as marketing tool for their publicity [3].

\section{Marketing}

The process of communicating the customer for the purpose of selling the product or producing the services to the customer which are required by them is known as marketing. When we want to get into market with a product firstly a small research on the product in the market is required. While starting a market research we need to consider the consumers' requirement their wishes and aspirations, these are the things by which a product can grab lot of customers towards it. The following table shows the statistics of internet users in the world (Table 1).

The stats provided by the organization "internet world stats" shows that $30 \%$ of world's population is using internet for search of information and for gaining knowledge.Facebook has nearly 500 hundred million users around the world; in a conducted survey it states that internet users are spending more time with Facebook when compared with Google, Yahoo and YouTube. Consumers trust their friends and family when compared with other sources for product and service information. As Facebook in a most popular social networking site people started making decisions on Facebook directly with their friends and family members. $70 \%$ of the brands around the world are planning to increase their investment in internet marketing instead of investing on the other marketing resources [4].

\section{Discussion}

The purpose of this study is to show how the companies are using Facebook and internet as their marketing tool for projecting their product, according to the above given information we can state that Facebook users and internet users are drastically increasing in number, making this as note companies started marketing their product in social media. Facebook is standing as platform for smart or net marketing for the companies as the users of Facebook are getting increased day by day Facebook started marketing the different company's product by creating a special page on the name of company, based on the number of likes and shares of the particular page they started charging the price for the company, in this modernized world Facebook has become the best platform for marketing. There are many tips for the people from different parts of the world about how to market their product in Facebook in an attractive manner. 
Citation: Sriteja V, Vinay V, Hemalal R, Sushma B, Venkatesh TV (2014) Marketing in Facebook. J Socialomics 3: R1001. doi:

Page 2 of 2

\begin{tabular}{|l|l|l|l|l|l|l|}
\hline \multirow{2}{*}{ Woad Regions } & Population & Internet Users & Internet Users & Penetration & Growth & Users \\
\cline { 2 - 7 } & ( 2011 Est.) & Dec. 31, 2000 & Latest Data & I\% Population) & $\mathbf{2 0 0 0 2 0 1 1}$ & of Table \\
\hline Ahica & 1,037524 Dse & $4,514,400$ & 139.875 .242 & $135 \%$ & $29884 \%$ & $62 \%$ \\
\hline Asia & $3879.740,877$ & $114,304,000$ & $1,016.799 .076$ & $262 \%$ & $7896 \%$ & $448 \%$ \\
\hline Emope & $816,426,346$ & 105.096 .093 & 500.723 .686 & $613 \%$ & $3764 \%$ & $221 \%$ \\
\hline Middle East & $216.258,843$ & 3.284 .830 & 77.020 .995 & $356 \%$ & $22448 \%$ & $34 \%$ \\
\hline Houk America & $347,394,870$ & 108096.83 & 273.067 .546 & $786 \%$ & $1526 \%$ & $120 \%$ \\
\hline $\begin{array}{l}\text { Latin America i? } \\
\text { Catib. }\end{array}$ & $597,283,165$ & $180 \mathrm{E} 8,919$ & 235.81934 & $395 \%$ & $12051 \%$ & $104 \%$ \\
\hline $\begin{array}{l}\text { Oceania } \\
\text { Ausitalla }\end{array}$ & $35,426,995$ & $7,620,480$ & 23.927 .457 & $575 \%$ & $2140 \%$ & $11 \%$ \\
\hline WORLD TOTAL & $6,930.055 .151$ & $360,985.19$ & 2267.233 .712 & $32.70 \%$ & $528.10 \%$ & $100.00 \%$ \\
\hline
\end{tabular}

Table 1: World Internet Usage and Population Statistics December 31. 2011

\section{Conclusion}

From the start of Facebook it has been in news for its special and attractive designing of its page, it started attracting people all over the world, soon when it got started attracting the people it made a platform between the companies and the people through Facebook page which has become a best platform for a smart marketing in net. As the net users are getting increased day by day Facebook planed their strategies to market products on their site. Facebook projected its site as a best platform for marketing.

\section{Reference}

1. http://en.wikipedia.org/wiki/Facebook

2. Jeremiah Owyang, Christine Tran, Alan Webber (2010) The 8 Success Criteria For Facebook Page Marketing.

3. Adelina Eugenia Ivanov (2012) The Internet impact on integrated marketing communication. 3: 536-542.

4. Elena-Iulia Apavaloaie (2012) Marketing research regarding the Internet usage among the population of the Mures County. 3: 928-934 